\title{
Assessment of Nutritional Status among Postmenopausal Women of Jorhat, Assam, India
}

\author{
Mansi Tiwari*, Mridula Saikia Barooah, Ruma Bhattacharyya, \\ Premila L. Bordoloi and Moloya Gogoi
}

\author{
Department of Food Science and Nutrition, College of Community Science, Assam \\ Agricultural University, Jorhat - 785013, Assam, India
}

*Corresponding author

\section{Keywords}

Post menopause,

Early menopause,

Nutritional status,

Nutrient intake

\section{Article Info}

Accepted:

05 February 2020

Available Online:

10 March 2020

\section{A B S T R A C T}

Menopause is the period of transition in the life of women during which several physiological changes occurs. This period not only marks the end of reproductive cycle of women but also makes them vulnerable to several chronic diseases such as cardiovascular disease, osteoporosis, diabetes, gastritis, asthmas, liver disease etc. Food and other lifestyle factors greatly affect the health status of post menopausal women. This demands special care and attention to the women during this phase. The present study was carried out in Jorhat city of Assam with a sample size of 100 with the aim to assess the nutritional status of post menopausal women. Simple random sampling was employed for selection of sample. Only those women who have attained menopause were selected for the study. The data from respondents were collected by means of a structured questionnaire and mean nutrient intake of the respondents were recorded by employing 24 hour recall method. The mean age of attainment of menopause among the respondents was $48.58 \pm 3.38$ years and majority of respondents attained menopause between the ages of 45-50 years. A significant association $(\mathrm{p}<0.05)$ of physical activity pattern and BMI with menopausal age of the respondents were observed. Menopausal age was also found to be associated significantly $(\mathrm{p}<0.05)$ with diabetes, gastritis and bone disease. The result of dietary assessment showed a poor dietary intake by the women. The mean protein intake was found $47.15 \pm 19.21$ $\mathrm{g}$ /day which was $14.27 \%$ lower than the RDA. The diet of the respondents were also deficit in minerals with mean calcium, magnesium, phosphorus and iron intake of $479.36 \pm 183,116.25 \pm 87.39,519.68 \pm 165.45$ and $17.03 \pm 8.34 \mathrm{mg} /$ day. However higher intake of carbohydrate and fat was recorded among the studied population. The study shows that the post menopausal women of Jorhat of Assam have poor nutritional status and therefore requires special attention. 


\section{Introduction}

Menopause, a stage marked by permanent cessation of menstrual cycle is one of the most challenging periods in the life of women. It usually occurs between the ages of 45-55 years. During this period there is loss of follicular activity of ovaries which is accompanied with change in hormonal levels leading to drop in the levels of estrogen and progesterone. WHO defined post menopausal women as those who naturally stopped menstruating a year before or those who stopped having periods as a result of some medical or surgical intervention (WHO, 1996). They are at increased risk of developing certain chronic diseases like heart disease, hypertension, diabetes, sleep apnea, cancer, osteoarthritis and other mental health problems (Dennis, 2007). However the extent and severity of these problems vary from person to person depending upon their lifestyle, social and physiological status (Kothiyal and Sharma, 2017).

With advancement in medical science and other health care facilities, the life expectancy has increased. Today around $1 / 3^{\text {rd }}$ of women spend their life in post-menopausal phase (Vaze and Joshi, 2010). During this period there is multifactorial interaction between psychological, social and environmental factors which has made the overall health and well being of middle aged women a major public health issue (Kothiyal and Sharma., 2013). Diet is also an underlying factor that affects the health and nutritional status of menopausal women (Gold et al., 2001). A diet rich in phytoestrogen, fiber and low in fat especially saturated fat is recommended during this period (Unni, 2010). Menopausal women are at increased risk of developing bone diseases such as osteoporosis, osteopenia, arthritis, joint pain etc. due to increased loss of bone mass density during this period due to fall in the level of estrogen which helps in positive calcium metabolism (Thulkar and Singh, 2015). Therefore during this period requirement of vitamin $D$, calcium, magnesium and other minerals increases. Considering the importance of nutrition during this period, the present study was conducted to study the nutritional status of the post-menopausal women of Jorhat city of Assam.

\section{Materials and Methods}

A community based survey was carried out among post-menopausal women of Jorhat city of Assam to assess their nutritional status. The study was conducted during the period of February, 2018 to May, 2018 with a sample size of 100 respondents. Those women who were more than 40 years in age and those who had their last menstruation before one year were selected by employing simple random sampling. Information on socio-economic factors like age, educational qualification, income, family type, occupation etc., activity pattern, menopausal age and medical history were collected with the help of a structured questionnaire.

The nutritional status of the respondents was assessed by means anthropometric assessment. Height, weight and Body Mass Index (BMI) of the respondents were measured. The height and weight of the respondents were taken with the help of measuring tape and a portable digital weighing balance respectively using standard technique. Body Mass Index of respondents was determined as the ratio of weight in $\mathrm{Kg}$ per height in squared metre and the respondents were grouped as underweight, normal, overweight and obese as per the BMI classification given by WHO. The data concerning dietary intakes of the respondents were collected using 24 hour recall method. The dietary intakes for three successive days were recorded from the respondents. The 
respondents were asked to recall their dietary intake of the previous day. From the results of 24 hour recall method, mean daily nutrient intake was estimated using Indian Food Composition Table (Longvah et al., 2017).

The data collected using different tools were coded and tabulated to facilitate the effective interpretation of results. Data was analyzed statistically using the SPSS version 20 and MS Excel 2007. Frequency distribution, percentage, Chi-square test and correlation were applied to the data set wherever applicable. The level of significance was taken at $\mathrm{p}<0.05$ for the study.

\section{Results and Discussion}

\section{Socio-demographic profile}

The socio-demographic profile of the study population is presented in Table 1. The mean age of the studies population was 57 years with majority of the population (47\%) between 50 to 60 years. Among the studied population $84 \%$ of the population was married, $15 \%$ were widowed while only $1 \%$ population was single. Most of the respondents in the studied population were Hindu (87\%) and majority belonged to lower economic status (42\%). Of the total surveyed population, $9 \%$ were illiterate while 17 per cent of the population had completed their higher education. The physical activity among the population was found very less with 60 per cent of the population having sedentary lifestyle.

The mean menopausal age of the respondents in the study were $48.58 \pm 3.38$ which is quite similar to the study of Abdollahi et al., (2013) and Mortazavimoghadam et al., (2004). The attainment of menopause prior to 45 years of age is called early menopause and after 50 years is termed as late menopause (Ahmed et al., 2016) both of which are associated with certain types of health complications.
Majority $(54 \%)$ of the respondents in the study attained menopause between the ages of 45-50 years while 19 per cent of the respondents attained menopause between the age of 40-45 years i.e. early menopause.

Menopausal age varies with person, region, countries and ethnic groups (Thomas et al., 2001). The variation might also be due to difference in genetic makeup (Murabito et al., 2005) or due to differences in socioeconomic, environmental or other lifestyle factors (Schoenaker et al., 2014). Table 2 shows the association of socio-economic status, educational qualification and physical activity level of the population with menopausal age of the respondents. No significant $(p>0.05)$ association was observed between educational status and menopausal age. Reynolds and Obermeyer in 2001 also obtained no significant association between education and menopausal age in a study conducted in Lebanese population. However, the studies of Fu et al., (2016) and Do et al., (1998) revealed that higher education is associated with later menopausal age.

Results showed no significant association between socio-economic status and menopausal age $(p>0.05)$ of the respondents. Similar finding was observed in the study of Abdollahi et al., (2013) in which no significant association between socioeconomic status and menopausal age was observed ( $\mathrm{p}>0.05)$.

In the study the physical activity was found to be significantly $(\mathrm{p}<0.05)$ associated with the menopausal age in which the heavy workers tend to attain menopause early. The findings have close resemblance with the study of Fu et al., (2016) which showed that physical laborers which include production workers, farmers, and service workers who are basically heavy workers had earlier menopause than unclassified workers which included officers, technical staff, students, the 
unemployed, and retirees. Contrary to these, the study of Abdollahi et al., (2013) showed no significant association ( $p>0.05)$ between physical activity and menopausal age.

\section{Nutritional status}

The nutritional status of the respondents in terms of Body Mass Index (BMI) are presented in Table 3. The BMI of the individuals were compared with the BMI classification table given by WHO. Among the total respondents 12.00 per cent the respondents were underweight, 46.00 per cent were normal, 36.00 per cent were overweight and 6.00 per cent of the respondents were obese.

Fig. 1 shows the correlation of BMI of the individuals with the age of attainment of menopause. A very strong correlation with $r=0.549$ was observed between increase in BMI and menopausal age $(\mathrm{p}<0.01)$. Women who were underweight $(\mathrm{BMI}<18.50)$ attained menopause at early age compared to the women who were overweight and obese in the present study. The study of Morris et al., 2012 also revealed a significant increase in menopausal age with the increase in BMI $(\mathrm{P}<0.01)$. Similar results were obtained by Rodstrom et al., (2003) in their study in which they reported that increased BMI was associated with onset of menopause in later part of life.

\section{Medical history}

Age at onset of menopause may be associated with several health problems. Since menopause is a period of transition, women during this period are prone to several disease conditions which calls for special attention and requires periodic health checkups to avoid future complications. The results on the medical history of the respondents and its association with menopausal age are shown in Table 4. The results of medical history of the respondents revealed that bone disease (48\%), gastritis (45\%), migraine (36\%) and diabetes (32\%) were more prevalent among the studied population. The results of the study suggest that there is a significant association $(p<0.01)$ between menopausal age and diabetes. Several other studies have also determined the association between diabetes and menopausal age and found that there is strong association between diabetes and menopausal age (Brand et al., 2015 and Brand et al., 2013). As per Yarde et al., (2015), Type 1 diabetes increases the risk of earlier depletion of ovarian follicle which further increases the chance of menopause at earlier age.

In the present study menopausal age was found to be significantly $(\mathrm{p}<0.05)$ associated with gastritis which is similar to the study of Fu et al., (2016) in which there was association between gastroenteritis and menopausal age. It was also found in the study of Lichtarowocz et al., (1989) that compared to healthy women those with Chron's disease had early menopause indicating an association of chronic gastritis with menopausal age.

The research outcome also shows a significant association $(\mathrm{p}<0.01)$ between bone disease and menopausal age. As per studies women who attain menopause before the age of 45 years have lower bone mass density which in associated with poor bone health (Popat et al., 2009).

\section{Dietary habit}

Majority of the respondents $(78.00 \%)$ in the population were non-vegetarian and only 22 per cent were vegetarian. Of the total population major portion $(64.00 \%)$ consumed meals thrice a day whereas 23.00 per cent of the population consumed meal four times a day and only 13.00 per cent consumed meal two times a day. 
Table.1 Socio-demographic profile of the study population

\begin{tabular}{|c|c|c|c|}
\hline Parameters & Category & $\begin{array}{c}\text { Frequency } \\
(\mathbf{n}=100)\end{array}$ & Percentage \\
\hline Age in years & $\begin{array}{l}40-50 \text { years } \\
50-60 \text { years } \\
60-70 \text { years } \\
70 \text { years \& above }\end{array}$ & $\begin{array}{l}22 \\
47 \\
20 \\
11\end{array}$ & $\begin{array}{l}22 \% \\
47 \% \\
20 \% \\
11 \%\end{array}$ \\
\hline Religion & $\begin{array}{l}\text { Hindu } \\
\text { Muslim } \\
\text { Christian }\end{array}$ & $\begin{array}{c}87 \\
11 \\
2\end{array}$ & $\begin{array}{c}87 \% \\
11 \% \\
2 \%\end{array}$ \\
\hline Marital status & $\begin{array}{l}\text { Single } \\
\text { Married } \\
\text { Widowed }\end{array}$ & $\begin{array}{c}1 \\
84 \\
15\end{array}$ & $\begin{array}{c}1 \% \\
84 \% \\
15 \%\end{array}$ \\
\hline Socio-economic status & $\begin{array}{l}\text { Upper } \\
\text { Upper middle } \\
\text { Lower middle } \\
\text { Lower }\end{array}$ & $\begin{array}{l}11 \\
20 \\
27 \\
42\end{array}$ & $\begin{array}{l}11 \% \\
20 \% \\
27 \% \\
42 \%\end{array}$ \\
\hline Educational status & $\begin{array}{l}\text { Illiterate } \\
\text { Below primary } \\
\text { Primary } \\
\text { Above primary } \\
\text { Higher education }\end{array}$ & $\begin{array}{c}9 \\
12 \\
24 \\
38 \\
17\end{array}$ & $\begin{array}{c}9 \% \\
12 \% \\
24 \% \\
38 \% \\
17 \%\end{array}$ \\
\hline Physical activity level & $\begin{array}{l}\text { Sedentary } \\
\text { Moderate } \\
\text { Heavy }\end{array}$ & $\begin{array}{l}60 \\
25 \\
15\end{array}$ & $\begin{array}{l}60 \% \\
25 \% \\
15 \%\end{array}$ \\
\hline Age at menopause & $\begin{array}{l}40-45 \text { years } \\
45-50 \text { years } \\
50-55 \text { years }\end{array}$ & $\begin{array}{l}19 \\
54 \\
27\end{array}$ & $\begin{array}{l}19 \% \\
54 \% \\
27 \%\end{array}$ \\
\hline
\end{tabular}

Table.2 Association of socio-economic status, educational qualification and physical activity pattern to menopausal age

\begin{tabular}{|c|l|c|c|c|c|}
\hline Parameter & \multicolumn{1}{|c|}{ Categories } & \multicolumn{3}{|c|}{ Menopausal age } & \multicolumn{1}{c|}{$\boldsymbol{P}$} \\
\cline { 2 - 5 } & & $\mathbf{4 0 - 4 5}$ years & $\mathbf{4 5 - 5 0}$ years & $\mathbf{5 0 - 5 5}$ years & value \\
\hline Socio-economic & Upper & 1 & 6 & 4 & 0.18 \\
status & Upper middle & 0 & 13 & 7 & \\
& Lower middle & 6 & 14 & 7 & \\
& Lower & 12 & 22 & 8 & \\
\hline Educational & Illiterate & 3 & 5 & 1 & 0.37 \\
qualification & Below primary & 4 & 7 & 1 & \\
& Primary & 5 & 10 & 9 & \\
& Above primary & 6 & 22 & 10 & \\
\hline Physical activity & Higher education & 1 & 11 & 5 & \\
pattern & Sedentary & 4 & 30 & 25 & 0.00 \\
& Moderate & 7 & 18 & 0 & \\
\hline
\end{tabular}

The level of significance was considered at $\mathrm{p}<0.05$ 
Table.3 Distribution of respondents according to their nutritional status

\begin{tabular}{|l|c|c|}
\hline \multicolumn{1}{|c|}{ Nutritional status } & BMI (Kg/m $\left.\mathbf{m}^{\mathbf{2}}\right)$ & Per cent of respondents \\
\hline Underweight & $<18.50$ & $12.00 \%$ \\
\hline Normal & $18.50-24.99$ & $46.00 \%$ \\
\hline Overweight & $25.00-29.99$ & $36.00 \%$ \\
\hline Obese & $>30.00$ & $6.00 \%$ \\
\hline
\end{tabular}

Table.4 Association of chronic diseases with the menopausal age of the population

\begin{tabular}{|c|c|c|c|c|c|}
\hline \multirow[b]{2}{*}{ Chronic diseases } & \multirow[b]{2}{*}{$\begin{array}{c}\text { Percentage } \\
(\%)\end{array}$} & \multicolumn{3}{|c|}{ Menopausal age } & \multirow[b]{2}{*}{$P$ value } \\
\hline & & 40-45 years & 45-50 years & 50-55 years & \\
\hline Diabetes & $32 \%$ & 12 & 14 & 6 & 0.005 \\
\hline Hypertension & $18 \%$ & 0 & 12 & 6 & 0.07 \\
\hline Migraine & $36 \%$ & 10 & 18 & 8 & 0.24 \\
\hline Gastritis & $45 \%$ & 14 & 22 & 9 & 0.01 \\
\hline Bone disease & $48 \%$ & 16 & 23 & 9 & 0.002 \\
\hline Asthma & $9 \%$ & 0 & 7 & 1 & 0.14 \\
\hline Liver disease & $4 \%$ & 2 & 2 & 0 & 0.20 \\
\hline
\end{tabular}

The level of significance was considered at $\mathrm{p}<0.05$

Fig.1 Correlation between menopausal age and BMI of respondents

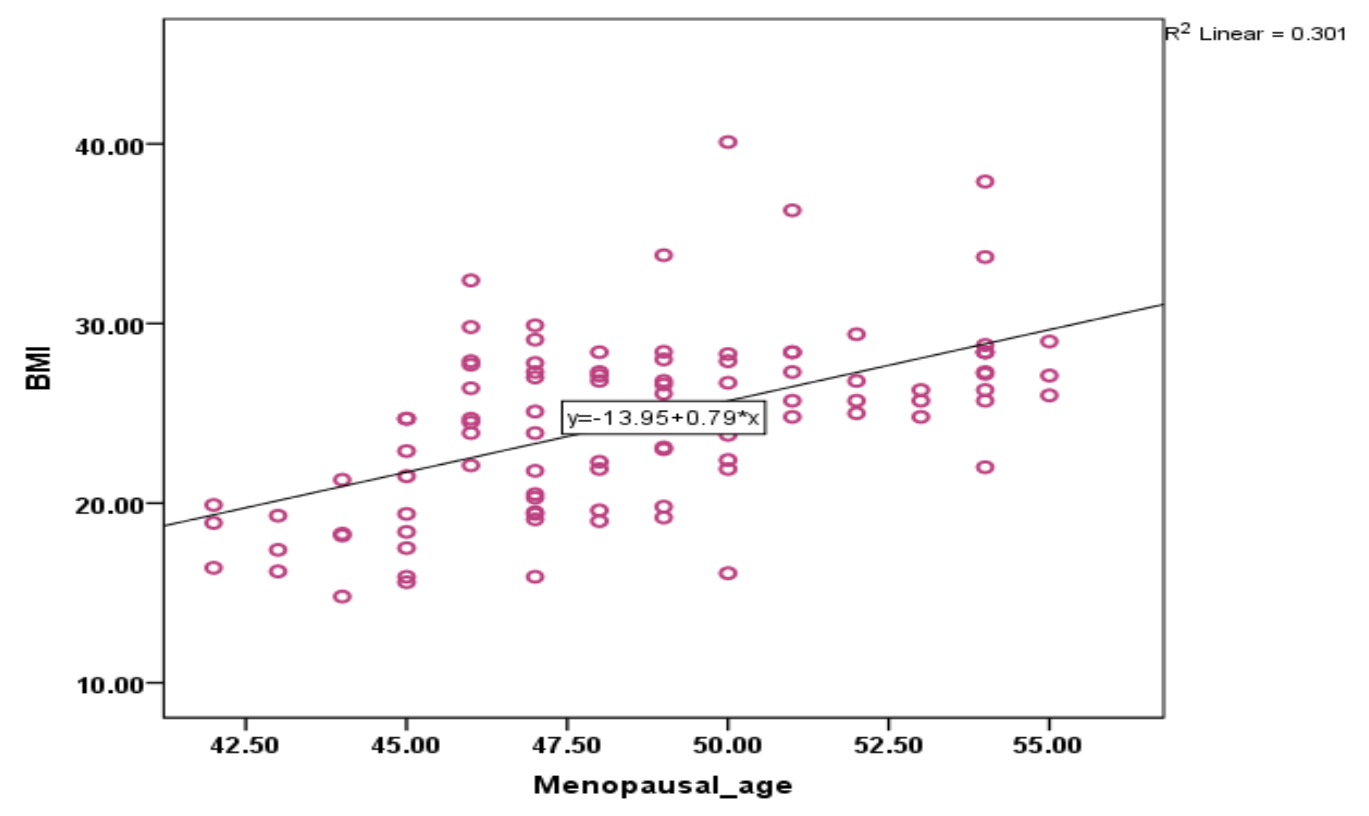


Table.5 Mean nutrient intake of the target population

\begin{tabular}{|l|l|c|c|}
\hline Nutrient & Mean Intake & $\begin{array}{c}\text { RDA for sedentary } \\
\text { women }\end{array}$ & $\begin{array}{c}\text { \% of excess or } \\
\text { deficiency }\end{array}$ \\
\hline Energy (Kcal/day) & $1988.63 \pm 584.63$ & 1880 & $5.78+$ \\
\hline Protein (g/day) & $47.15 \pm 19.21$ & 55 & $14.27-$ \\
\hline Fat (g/day) & $42.67 \pm 9.80$ & 20 & $113.35+$ \\
\hline Calcium (mg/day) & $479.36 \pm 183$ & 600 & $20.11-$ \\
\hline Magnesium (mg/day) & $116.25 \pm 87.39$ & 310 & $62.5-$ \\
\hline Phosphorus (mg/day) & $519.68 \pm 165.45$ & 800 & $35.04-$ \\
\hline Iron (mg/day) & $17.03 \pm 8.34$ & 21 & $18.90-$ \\
\hline
\end{tabular}

The data on meal skipping pattern of the respondents showed that among the total population 38.00 per cent of the population skips meals of which 28.00 per cent skips breakfast, 7.00 per cent skips lunch and only 3.00 per cent of the population skipped lunch. However 62.00 per cent of the respondents did not skipped any meals of the day.

\section{Mean nutrient intake}

The mean nutrient of the study population was determined and the result of analysis is presented in Table 5. The studied population had a poor nutrient intake. When compared to the recommended dietary intake for adult women performing sedentary activity it was observed that the mean nutrient intake of most of the nutrient was lesser than what is recommended for their age group. The mean intake of protein of the studied population was 14.27 per cent lesser than the RDA and along with that the mean intake of micronutrients i.e. calcium, magnesium, phosphorus and iron was also than what is recommended for them. This lower mean nutrient intake was mainly attributed to their composition of diet which consisted less of protein and mineral rich foods. However the mean total energy intake of the population was 5.78 per cent excess than the recommended total energy. The greater mean energy intake may be due to higher intake of fat and carbohydrate rich food. The majority of the calorie in their die was contributed by fat and carbohydrate where as the calorie contribution of protein to total energy was comparatively lesser. Several other studies have also reported nutritional inadequacy among the people in this group of population (Berner et al., 2002; Volkert et al., 2004).

In conclusion, the health of post-menopausal women demands special care and attention due to increased life expectancy. This has resulted a major part of the life of women in this phase. Women during this phase are more vulnerable to several health problems due to the physiological changes occurring during this period. The women in the present study had poor nutritional status. The mean nutrient intake of the post-menopausal women was not adequate to meet the daily requirement of the population.

\section{Acknowledgement}

The authors are thankful to all members of the Department of Food Science and Nutrition, College of Community Science, Assam Agricultural University for their support in conducting the research. They are also thankful to all the respondents who contributed to the research by providing necessary information.

\section{References}

Abdollahi, A,A., Qorbani, M., Asayesh, H., Rezapour, A., Noroozi, M., 
Mansourian, M., Soleimani, M.A and Ansari, H. 2013. The menopausal age and associated factors in Gorgan, Iran. Med. J of the Islam. Repub. Iran. 27(2): 50 .

Ahmed, K., Jahan, P., Nadia, I and Ahmed F. 2016. Assessment of menopausal symptoms among early and late menopausal midlife Bangladeshi women and their impact on the quality of life. J Menopausal med. 22(1): 39-46.

Berner, Y.N., Stern, F., Polyak, Z and Dror, Y. 2002. Dietary intake analysis in institutionalized elderly: a focus on nutrient density. J Nutr. Health Aging. 6(4):237-42.

Brand, J.S, Onland-Moret, N.C., Eijkemans, M.J.C., Tjonneland, A., Roswall, N., Overvad, K., Fagherazzi, G., ClavelChapelon, F., Dossus, L., Lukanova, A and Grote V. 2015. Diabetes and onset of natural menopause: Results from the European Prospective Investigation into Cancer and Nutrition. Hum. Reprod. 30(6):1491-1498.

Brand, J.S., van der Schouw, Y.T., OnlandMoret, N.C., Sharp, S.J., Ong, K.K., Khaw, K.T., Ardanaz, E., Amiano, P., Boeing, H., Chirlaque, M.D and ClavelChapelon, F. 2013. Age at menopause, reproductive lifespan, and type2 diabetes risk: Results from the epicinteract study. Diabetes Care. 36(4): 1012-1019.

Dennis, K.E. 2007. Postmenopausal women and health consequences of obesity. J Obstetric Gynecol. Neonat. Nurs. 36 (5) : 511-517.

Do, K.A., Treloar, S.A., Pandeya, N., Purdie, D., Green, A.C., Heath, A.C and Martin, N.G. 1998. Predictive factors of age at menopause in a large Australian twin study. Hum. Biol. 70: 1073-1091.

Fu, Y., Yu, Y., Wang, S., Kanu, J.S., You, Y., Liu, Y., Zhang, Y., Liu, Y., Li, B., Tao, $\mathrm{Y}$ and Kou C. 2016. Menopausal age and chronic diseases in elderly women: a cross-sectional study in Northeast China. Int. J Environ. Res. Public Health. 13(10): 936.

Gold, E.B., Bromberger, J., Crawford, S., Samuels, S., Greendale, G.A., Harlow, S.D and Skurnick J. 2001. Factors associated with age at natural menopause in a multi ethnic sample of midlife women. Am. J Epidemiol. 153:865-874.

Lichtarowicz, A., Norman, C., Calcraft, B., Morris, J.S., Rhodes, J and Mayberry, J. 1989. A study of the menopause, smoking, and contraception in women with Crohn's disease. QJM: Int. J Med. 72(1): 623-631.

Longhvah, T., Ananthan, R., Bhaskarachary, K and Venkaiah, K. 2017. Indian Food Composition Tables. National Institute of Nutrition, Hyderabad.

Mishra, S.K. 2011. Menopausal transition and postmenopausal health problems: a review on its bio-cultural perspectives. 3(4):233-7.

Morris, D.H, Jones, M.E., Schoemaker, M.J., McFadden. E., Ashworth, A and Swerdlow, A.J. 2012. Body mass index, exercise, and other lifestyle factors in relation to age at natural menopause: analyses from the breakthrough generations study. Am. J Epidemio. 175(10): 998-1005.

Mortazavimoghadam, G., Khazaee, Z and Izadpanah, A.M. 2004. Average of age at natural menopause and related factors in Birjand. J Shahekord University Med. Sci. 5:53-61.

Murabito, J.M., Yang, Q., Fox, C., Wilson, P.W and Cupples, L.A. 2005. Heritability of age at natural menopause in the Framingham Heart Study. J Clin. Endocrinol. Metab. 90:3427-3430.

P, Kothiyal and M, Sharma. 2017. Post menopausal quality of life and associated factors-a review. Am. J 
Pharm Res. 3(9): 7175-7183.

Popat, V.B., Calis, K.A., Kalantaridou, S.N., et al., 2014. Bone mineral density in young women with primary ovarian insufficiency: results of a three-year randomized controlled trial of physiological transdermal estradiol and testosterone replacement. J Clin. Endocrinol. Metab. 99(9):3418-3426.

Praveena, D. 2014. Nutritional status index of post-menopausal women and premenopausal women. Food Sci. Res. J. 5(2): 106-109.

Reynolds, R.F and Obermeyer, C.M. 2001. Age at natural menopause in Beirut, Lebanon: the role of reproductive and lifestyle factors. Ann. Hum. Biol. 28:21-29.

Rodstrom, K., Bengtsson, C., Milsom, I., Lissner, L., Sundh, V and Bjoürkelund, C. 2003. Evidence for a secular trend in menopausal age: a population study of women in Gothenburg. Menopause. 10(6): 538-543.

Schoenaker, D.A., Jackson, C.A., Rowlands, J.V and Mishra, G.D. 2014. Socioeconomic position, lifestyle factors and age at natural menopause: a systematic review and meta-analyses of studies across six continents. Int. J Epidemiol. 43(5):1542-1562.

Thomas, F., Renaud, F., Benefice, E., De Meeüs, T and Guegan, J.F. 2001. International variability of ages at menarche and menopause: patterns and main determinants. Hum. Biol.:271290.

Thulkar. J and Singh, S. 2015. Overview of research studies on osteoporosis in menopausal women since the last decade. J mid-life health.6(3): 104.

Unni, J. 2010. Third consensus meeting of Indian menopause society: A summary. J mid life health. 1(1): 43-47.

Vaze, N and Joshi, S. 2010. Yoga and menopausal transition. J Mid-life Health:1:56-8

Volkert, D., Kreuel, K., Heseker, H and Stehle P. 2004. Energy and nutrient intake of young-old, old-old and veryold elderly in Germany. Eur. J Clin. Nutr. 58(8):1190-200.

World Health Organization (WHO) Scientific Group: Research on the menopause in the 1990s: report of a WHO scientific Group. 1996.

WHO (World Health Organization), 1995. Physical status: The use and interpretation of anthropometry. Report of a WHO expert committee. WHO Tech. Rep. Ser., pp:854.

Yarde, F., van der Schouw, Y.T., de Valk, H.W., Franx, A., Eijkemans, M.J.C., Spiering, W., Broekmans, F.J., Fauser, B.C., Eland, I.A., Storms, F and Muller, A.F. 2015. Age at menopause in women with type 1 diabetes mellitus: the OVADIA study. Hum. Reprod. 30(2): 441-446.

\section{How to cite this article:}

Mansi Tiwari, Mridula Saikia Barooah, Ruma Bhattacharyya, Premila L. Bordoloi and Moloya Gogoi. 2020. Assessment of Nutritional Status among Postmenopausal Women of Jorhat, Assam, India. Int.J.Curr.Microbiol.App.Sci. 9(03): 1187-1195.

doi: https://doi.org/10.20546/ijcmas.2020.903.139 